\title{
RISK ANALYSIS OF VEGETABLES MARKETING IN RWANDA. A CASE OF CARROTS AND CABBAGES PRODUCED IN NORTHERN PROVINCE, RUBAVU DISTRICT AND SUPPLIED ACROSS THE COUNTRY
}

\author{
Jean Jacques Kubwimana ${ }^{凶}$
}

University of Rwanda, Rwanda

\begin{abstract}
Due to the perishable and biological nature of the vegetable production process, there is difficulty in scheduling the supply of vegetables to market demand. Vegetables are subjected to higher price, quality, and quantity risks because of changing consumer demand and production conditions. The core focus of this study was to reach, measure, and analyze the marketing risk level of vegetables produced in the Northern Province (Rubavu district), Rwanda. This study was based on a survey conducted with 90 vegetable sellers. At least 30 couple of wholesalers and middlemen visited the Rubavu district to trade the vegetables with various retailers across the country. The study used primary data collected through structured questionnaires and secondary data sources. A five-point Likert scale associated with the bivariate analysis was used to rank the risk level while the full models of linear regression analysis and factor analysis were used to identify the major risk factors affecting the Rwandan vegetable market. The mean score results derived from the Likert scale indicated that low prices of seasonal products, weak market channels, poor logistics and market communications, poor product handling and packaging, lack of storage and higher perishability were identified as the most important sources of risk. Therefore, the use of forward contracts, access to market information, selling at crude prices due to perishability, contractual arrangements, maintaining good relationships, and upgrading the storage network system were statistically significant measures for overcoming these risks.
\end{abstract}

Keywords: risk, risk analysis, Likert scale, marketing risk, vegetable marketing risk, risk management

\section{INTRODUCTION}

Risk in agriculture is pervasive and complex, especially in agricultural production, which can be termed a risky enterprise (Hardarker et al., 2004). Farmers and agricultural commodity sellers confront variable yields, unstable output and input prices and radical changes in production technology as inherent aspects of their daily farming operations. These affect the fluctuations in farm profitability from season to season and from one year to another (Dunn, 2002; Hossain et al., 2002).

The sources and severity levels of risk can vary according to farming systems, geographic location, weather conditions, support policies of the government, and farm types. Risk is a major concern in developing countries where agricultural value chain actors have imperfect information on forecasting things such as product prices and weather conditions which might impact agricultural commodities in the future (Nyikal and Kosura, 2005; Pannell et al., 2000). The sources of risk in agriculture are classified as business risks and financial risks (Hardarker et al., 2004). Business risks directly affect the profitability of agricultural commodities (Hardaker et al., 2004). In turn, the marketing or price risk is described as the fluctuation in the price of farm inputs and outputs affected by demand and supply in competitive markets. They include the unpredictability

\footnotetext{
$\triangle$ Jean Jacques Kubwimana, College of Agriculture and Veterinary medicine (CAVM), University of Rwanda, Busogo, Nothern Province, e-mail: kubwimanajeanjacques@gmail.com, https://orcid.org/0000-0002-5718-1661
} 
Kubwimana, J. J. (2020). Risk analysis of vegetables marketing in Rwanda. A case of carrots and cabbages produced in Northern Province, Rubavu District and supplied across the country. J. Agribus. Rural Dev., 2(56), 183-200. http://dx.doi.org/10.17306/ J.JARD.2020.01326

of agricultural supply, changes in consumer consumption behavior and incomes, international trade barriers, instability of currency exchange rates, and changes in accessibility and price of farm inputs (Hardarker et al., 2004; Shadbolt et al., 2005).

Due to the perishable and biological nature of the production process, there is difficulty in scheduling the supply of vegetables to market demand. Crops are subjected to higher price and quantity risks because of changing consumer demand and production conditions. Unusual production or harvesting weather or a major crop disease can have an adverse effect on the marketing system. Since the food marketing system requires a stable price and supply, some of the marketing arrangements (like contract farming) provide stability (Kohl and Uhl, 1985). The global per capita consumption of fruit and vegetables showed an increase of $0.38 \%$ for fresh fruit and $0.92 \%$ for vegetables from 1986 to 1995 . The lowest consumption of vegetables per capita was registered in sub-Saharan Africa (29 $\mathrm{kg}$ of vegetables consumed in 1986-1995). The trend toward fresh vegetable consumption in developing countries is an indicator of the population's standards of living. However, generally, fresh vegetables lose their market share to processed products. Many vegetables can be processed into canned products that cater to local tastes. Easy to carry and convenient to serve, they can be stored for a long time, reducing losses incurred from the seasonal supply of surplus vegetables marketed yearly at the same time. Urban population is exploding in developing countries, having risen from $35 \%$ of the total population in 1990, and projected to rise 54\% in 2020 (FAO, 2014).

In 2016, the Rwandan agricultural sector employed up to $80-90 \%$ of the total population. Farming with food crops for cash and own consumption is dominant, with an average farm area of around 0.5 ha. While Rwanda has a fertile ecosystem, food production is currently not sufficient to meet the demand, making the country partly dependent on imports (Youri et al., 2016). Rwanda has a mild tropical highland climate, suitable for horticultural production. Local temperatures are lower than what is typical for equatorial countries because of its high elevation (Dijkxhoorn et al., 2016). The limited resources of cultivable land are a major constraint. There has been little analysis of the structure of marketing channels for fruits and vegetables consumed domestically in fresh form, other than for sales by organizations. It is thought that over two-thirds of marketed horticultural production does not leave the district in which it is produced. Coupled with on-farm consumption, this suggests that at least three-quarters of production does not leave the district in which it is grown, being expended on a ranch, off-cultivated inside the district, or lost because of crumbling beyond use (Dijkxhoorn et al., 2016). Therefore, this study was conducted to reach, measure, and analyze the major sources of risk and risk management in vegetable marketing, based on perceptions of vegetable sellers who typically sell cabbages and carrots produced in the volcanic region of the Northern Province of Rwanda.

Most of the vegetable crops in Rwanda are produced on very small plots of land, usually as parts of a vegetable garden where the households primarily grow eggplant, cabbages, carrots and onions for home consumption and occasional selling. Cabbage and tomato are by far the most important vegetables in terms of area planted and production weight. National production is similar for both, but the area under cabbage is greater, reflecting its lower per-hectare yield. Local eggplants rank third in terms of area and weight. Carrots and onions are also of importance. The per-hectare yield of carrots is much higher than onions. As a consequence, the production of carrots exceeds that of onions despite carrots having a smaller planted area (NAEB, 2014a). The spatial distribution of cabbage production reflects its need for relatively cool growing conditions. Around $87 \%$ of the country's carrots originate from the western region, Rubavu district, accounting for over half of national production (NAEB, 2014a).

Vegetables produced in Rwanda are mostly transported by head load or bicycle and sometimes by truck. For most households, this requires considerable effort since-despite the country being small and densely populated - the hilly terrain means that the nearest market is often many miles away. While district markets around the country are well connected by road, getting to and from the market is a challenge for many rural households. Just $6 \%$ of families are served by a market inside their town. That rate is often low due to lack of local purchasing power and collusion between market traders (Dijkxhoorn et al., 2016). The main precise development of vegetable farmers inside the residential market in Rwanda is by traders' together transfers locally available to be purchased in Kigali. There are three main multipurpose wholesale and retail markets in Kigali where specialized fruit and vegetable wholesalers 
Kubwimana, J. J. (2020). Risk analysis of vegetables marketing in Rwanda. A case of carrots and cabbages produced in Northern Province, Rubavu District and supplied across the country. J. Agribus. Rural Dev., 2(56), 183-200. http://dx.doi.org/10.17306/ J.JARD.2020.01326

operate. They mostly trade in tomatoes, cabbages, onions and carrots. The three markets provide shelter and basic security for small fruit and vegetable traders who typically have stalls of $1.5 \mathrm{~m}^{2}$ each. Fruits and vegetables are traded as part of the general trading of goods such as shoes, clothes and kitchen utensils (NAEB, 2014b).

Knowing the nature of risks that affect vegetable sellers is the key to developing appropriate mitigation solutions. However, no empirical studies are available on how vegetable sellers respond to risks and how risk affects vegetable sellers' income in Rwanda, but some limited studies have been conducted in other developing countries. The perception of risk sources is the starting point for vegetable producers and sellers when making risk management decisions. A study was conducted by Matsane and Oyekale (2014) on factors affecting the marketing of vegetables among small-scale farmers in Mahikeng Local Municipality, Northwest Province, South Africa. The results showed that about $48.9 \%$ of farmers sold their produce both at farm gate and local village markets but farm gate was the prevailing option due to small production volumes, poor quality and lack of contract marketing. Their study also proved that most (57.4\%) vegetable producers were located more than 5 kilometers away from marketplaces. In the territory covered by this study, small-scale farmers stay in former homelands which are located far away from the market. This fact pushed $72.3 \%$ of vegetable farmers to adopt an individual marketing system (Matsane and Oyekale, 2014) lack of access to storage facilities, lack of market information, lack of finance for farming, poorly developed village markets, poor producer prices, high perishability of produce, low patronage, inadequate access roads, small size of transport and high transportation costs. Variables that significantly influenced monthly net farm income were: gender $(t=3.913$. A study conducted by Mutungul et al. (2001) at Impendle and Swayimani in KwaZulu-Natal discovered that the farmers normally sell their produce through informal channels such as neighbors and local shops. However, the local market is not sufficient to allow smallholder farmers to make substantial profits for them to grow and develop to larger-scale farming. People in remote rural areas are usually without jobs, lack purchasing power, and cannot afford to pay higher prices (Mutungul and Ortmann, 2001). They bargain for cheap prices and thus farmers do not obtain a better return for their produce. Linking smallholder vegetable farmers to high-value markets in the agricultural supply chain remains a major problem. There is need to identify the factors that are currently preventing smallholder vegetable farmers from participating in and benefiting from high-value markets.

The vegetable market price depends much more on vegetable production systems. In a study across Ghana, $56 \%$ of consumers accepted a maximum premium payment of $20 \%$ for organic vegetables (Osei-Asare, 2009). An even higher premium (of over 50\%) for organic fruits and vegetables was recorded by Owusu and Anifori (2012), and Coulibaly et al. (2011). For example, given a standard price of USD 0.25 for an average size head of cabbage or a pack of tomatoes treated with synthetic pesticides, Ghanaian consumers were willing to pay up to $57 \%$ and $50 \%$ more for organic cabbage and tomatoes, respectively (Coulibaly et al., 2011; Owusu and Anifori, 2012). In a study conducted by Nurah (2000) in Kumasi and Sunyani, about $49 \%$ of 217 consumers interviewed reported being concerned with pesticide residues but only $5 \%$ said this concern has prompted them to change their buying habits (Nurah, 2000).

The differences in perceptions of risk sources may be determined by such characteristics of agricultural sellers as age, experience, farm size, farm diversification, marketing channels used to sell products as well as personality, beliefs, and culture (Ahsan and Roth, 2010; Kisaka-Lwayo and Obi, 2010; Parker et al., 2012). Only limited attention has been paid to assessing the perceptions of risk sources and the use of risk management strategies for vegetables sold at the market.

Fakayode et al. (2012) conducted a study using a discriminant analysis and the Kruskal-Wallis oneway analysis of variance by ranks to test the risk attitude among the farmers and sellers of fruit and vegetables in the Osun State, Nigeria. The results of this study revealed that perishability of produce (a mean of 531.95 ), low price of produce (a mean of 507.57), poor product handling and packaging (a mean of 422.89) and poor market linkages (a mean of 372.96) were ranked from the $1^{\text {st }}$ to the $5^{\text {th }}$ strongest sources of market risk by vegetable sellers (Fakayode et al., 2012). According to Jacobs (2008), smallholder fresh vegetable farmers faced various risks when accessing the great market. Barriers to access food markets are primarily associated with an underdeveloped infrastructure, ranging from the non-existence of local market spaces to unreliable sources of market information. Factors such as poor 
Kubwimana, J. J. (2020). Risk analysis of vegetables marketing in Rwanda. A case of carrots and cabbages produced in Northern Province, Rubavu District and supplied across the country. J. Agribus. Rural Dev., 2(56), 183-200. http://dx.doi.org/10.17306/ J.JARD.2020.01326

infrastructure, lack of market transport, and the inability to conclude contractual arrangements are some of the factors preventing rural farmers from accessing formal markets (Jacobs, 2008).

Using a survey in an analysis of risks facing smallholder farmers in central and northeast Thailand on irrigated and rain-fed areas, Aditto (2011) evaluated the farmers' perception of risks they face when producing and selling vegetables and other agricultural commodities. The result proved that an unexpected variability of product price (a mean of 3.65), changes in government laws and policies (a mean of 3.10) and changes in Thailand's economic and political situation (a mean of 3.07) were ranked as main sources of risks whereas obtaining market information (a mean of 3.47 [75.9\%]) and spreading sales over several periods (a mean of 3.53 [53\%]) were mentioned as the best strategies to adopt for higher performance rates at the market among Thai vegetable sellers in the central region (Aditto, 2011). Ali and Kapoor (2008) evaluated the farmers' perception of risks they experience when producing fruits and vegetables in six districts in Uttar Pradesh, India. The farmers were asked to indicate their perception of risks using a fivepoint Likert scale; low prices for products and high perishability of fruits and vegetables were perceived as the highest risks within the market risk category. Regardless of how fruit and vegetable producers perceive risk sources in study, more than $50 \%$ of them indicated not using any risk management strategy (Ali and Kapoor, 2008).

Further, this research seeks to investigate the risk attitudes of vegetable sellers in Rwanda. Risk preferences influence vegetable sellers' decision-making on vegetables selling strategies, and can be used as the basis for an analysis of risks affecting the marketing of agricultural commodities. Therefore, three hypothesizes were tested, namely: (1) there was a significant positive relationship between the vegetables farmers' socioeconomic characteristics and decision-making; (2) the source of marketing risks had a statistically significant impact on the efficiency and profitability of vegetable marketing; and (3) the factors influencing farmers' attitudes towards risks in vegetable marketing were statistically significant.

\section{DATA AND METHODOLOGY}

\section{Study area}

Rwanda is bordered by Uganda to the north, Burundi to the south, DRC to the West, and Tanzania to the east, and has an estimated area of $26,338 \mathrm{~km}^{2}$. The country is divided into 4 provinces, namely: Northern, Southern, Eastern and Western Provinces, and Kigali City, and is further divided into 30 districts. Rwanda is located at latitudes between $1^{\circ} 02^{\prime} 40^{\prime \prime}$ and $2^{\circ} 50^{\prime} 16^{\prime \prime}$ south and longitudes between $28^{\circ} 51^{\prime} 29^{\prime \prime}$ ' and 30 $33^{\circ}$ '56" east (Sirven et al., 1974). Rubavu District lies in a higher mountain zone, with a large part being located in volcanic regions, and forms part of the Western Province. It lies approximately $145 \mathrm{~km}$ away from the city of Kigali and the only point of existence to the DRC in Northern Rwanda. It has a normal temperature of $21.5^{\circ} \mathrm{C}$ and a yearly precipitation of around $1200 \mathrm{~mm}$ to $1300 \mathrm{~mm}$ (MININFRA, 2016).

\section{Sampling procedures}

According to Shaughnessy et al. (2003), the sample size is defined as a subset of the population of the sampling frame (Shaughnessy et al., 2003). A multistage sampling technique was used to select the respondents. The sampling procedure started with a simple random sampling method. Then, cluster sampling was performed among vegetable wholesalers, middlemen, and retailers. According to Kumar (2005), cluster sampling is based on the researcher' ability to divide the sampling population into groups called clusters, and then to select elements within each cluster using stratified or simple random sampling (Kumar, 2005). The cluster sampling method resulted in a subdivision into 2 clusters. Thirty-five vegetable traders and middlemen visited a volcanic region once a week and supplied their products to 80 vegetable retailers. The sample size in this study was calculated from the following formula given by Yamane (1973):

$$
\mathrm{n}=\frac{N}{1+N e^{2}}
$$

where: $n=$ sample size; $N=$ population size; and $e=$ acceptable error (5\%) (Yamane, 1973).

Using a 5\% acceptable error, the sample size of 90 individuals included 30 vegetable wholesalers; middlemen and 60 retails were randomly selected. However, the sample size can be different from that calculation, which based on not selling or selling various types of the vegetables whereas carrots and cabbages were not included, and other limitations (Scheaffer et al., 2006).

\section{Method of data collection}

The methodology employed in this study used both qualitative and quantitative research approaches. The 
Kubwimana, J. J. (2020). Risk analysis of vegetables marketing in Rwanda. A case of carrots and cabbages produced in Northern Province, Rubavu District and supplied across the country. J. Agribus. Rural Dev., 2(56), 183-200. http://dx.doi.org/10.17306/ J.JARD.2020.01326

qualitative method employed in this study for an in-depth analysis of the most important sources of risk factors among vegetable sellers in Rwanda was a quantitative approach focused on statistics and figures based the data confirmed by vegetable marketers. Marketing data was obtained at farm gate and at local, regional and national market level. Two techniques were employed to gather primary data, namely group interviews and in-depth individual face-to-face interviews. The structured interview questionnaire method was employed to elicit information from vegetable sellers on different markets visited.

The questionnaire consisted of both open-ended and closed-ended questions. The questionnaires had 4 main sections; the first one related to general information. The second section was designed to retrieve information on vegetable marketing incomes. The third focused on the sources of risk while section 4 was about risk management strategies. The third and fourth sections measured the importance of sources of risks and risk management strategies. A five-point Likert scale ranging between 1 (not important), to 5 (extremely important) through 3 (quite important) was used to access information on risk sources and risk management strategies. Interviews were carried out at the vegetable selling place. Secondary data was collected from different libraries such as the National Library, University of Rwanda Library and those kept by MINAGRI and NAEB. During the data collection process, the participants were told about the objective of the study and how the study could affect them.

\section{Method of data analysis}

Data collected from different markets and vegetable farms was analyzed with STATA version 14. Descriptive statistics such as percentages and frequency distribution, arithmetic means, tests of statistically significant differences (including the independent t-test and chi-square test) were used to identify the major sources of risk and risk management strategies. The purpose was to determine the difference between the vegetable sellers' socioeconomic characteristics and to rank risk sources and risk management strategies according to their intensity are more affected or adopted by the vegetable sellers.

The aggregated score of the refined statement for each vegetable seller refers to his/her risk perceptions. This score was used in the subsequent multiple regression analysis (labeled as the risk perception scale). The vegetables sellers' perceptions of risk sources and risk management strategies were studied based on a bivariate analysis. Before that, factor analysis was used to reduce the number of variables covered by risk sources and risk management strategies. Also, the Explanatory Factor Analysis (EFA) was performed as an essential empirical tool used in various subjects like economics, social sciences, psychology and political sciences in order to reduce the large number of variables relating to risk sources and risk strategies. The reliability test evaluates the contribution of individual scale items in the common underlying construct. A metric frequently used to evaluate the reliability is the Cronbach's alpha coefficient (DeVellis, 1991; Hair et al., 2010; Nunnally and Bernstein, 1994; Peter, 1979). The alpha coefficient measures the proportion of total variation due to true differences in vegetable sellers' risk management patterns. It is measured as

$$
\alpha=K /(K-1)\left(1-\left(\Sigma \sigma_{i}^{2}\right) /\left(\sigma_{y}^{2}\right)\right.
$$

where $\alpha$ is the Cronbach's alpha coefficient, $K$ is the number of statements in the scale, $\sigma_{i}^{2}$ is the variance of the $i^{\text {th }}$ statement, and $\sigma_{y}^{2}$ is the variance of the $k$-statement scale.

The coefficient varies in the range of 0 to 1 . In the explanatory factor analysis (EFA), a Cronbach's alpha value of 0.6 is considered to be the lower limit accepted by (Cox and Flin, 1998; Hair et al., 2010; Harvey et al., 2002). Factors with a latent root criterion (eigenvalue) greater than 1 were considered in this study, which means each factor contributes to a more considerable variance than had been possible by any one of its variables. When it comes to factor loadings, a minimum threshold of 0.3 is typically accepted in the literature, even though other authors suggest using the minimal range of $0.4-0.5$ for practical purposes (Von-Pork, 2007). In this study, values greater than or equal to 0.4 were employed to determine the inter-correlation among the original variables (Stevens, 1992).

The Kaiser-Meyer-Olkin (KMO) method measures the sampling adequacy and varies in the range of 0 to 1 . A KMO of 1 means that each variable is perfectly predicted without error by other variables. A KMO of 0.6 or more is recommended (Hair, 2006). Von-Pork (2007) explained that a KMO value greater than or equal to 0.50 is considered to meet the minimum level in the literature (Von-Pork, 2007). A multiple linear regression analysis was carried out to investigate the factors of results attitudes and perceptions based on the study's approaches. 
Kubwimana, J. J. (2020). Risk analysis of vegetables marketing in Rwanda. A case of carrots and cabbages produced in Northern Province, Rubavu District and supplied across the country. J. Agribus. Rural Dev., 2(56), 183-200. http://dx.doi.org/10.17306/ J.JARD.2020.01326

Based on linear regression, the researcher predicts a dichotomous outcome. According to Jari (2009), citing Gujarati (1995), linear regression does not assume a linear relationship between the dependent variable and independent variables. It requires independent linearly related to the regression of dependent variables (Jari, 2009). In linear regression, $Y$ is generally a binary variable (i.e. is either 0 or 1). This study assumes that two outcomes are possible, namely "positive perception of risk sources or risk management" or "negative perception of risk sources or risk management." The binary variable $\mathrm{Y}=1$ in cases where vegetable sellers have a positive perception of risk sources or risk management, and $\mathrm{Y}=0$ if vegetable sellers have a negative perception of risk sources or risk management. According to Gujarati, the functional equation of the linear regression model is described as follows (Gujarati, 1995):

$$
\text { Linear equation } E\left(Y_{i}\right)=\beta_{1} X_{i 1}+\beta_{2} X_{i 2}+\ldots+\beta_{p} X_{i p}(1)
$$

For the outcome $Y_{i}$ to take a binary value, a special function $f\left(E\left(Y_{i}\right)\right)$, referred to as the linear function, has to be found.

$$
\begin{aligned}
& \text { Linear function } f\left(E\left(Y_{i}\right)\right)= \\
& \alpha+\beta_{1} X_{i 1}+\beta_{2} X_{i 2}+\ldots+\beta_{p} X_{i p}
\end{aligned}
$$

The formula of the logistic regression model with outcome $\mathrm{Y}_{\mathrm{i}}$ is as follows:

Linear regression model formula with outcome $Y_{i}$ :

$$
\begin{gathered}
\text { Linear }(P i)=\ln \left(p_{i} / 1-p_{i}\right)=\beta_{0}+\beta_{1} X_{i 1}+ \\
\beta_{2} X_{i 2}+\beta_{p} X_{i p}+\varepsilon_{t}
\end{gathered}
$$

with: $\ln \left(p_{i} / 1-p_{i}\right)=$ Linear for vegetables sources of risk / risk management decisions, $p_{i}=$ perception of risk sources / risk management, $1-p_{i}=$ no perception of risk sources $/$ risk management, $\beta_{0}=$ intercept, $\beta_{1} \beta_{n}=$ coefficients, $X=$ independent variables, and $\varepsilon=$ error term.

\section{RESULTS AND DISCUSSION}

The aggregated statistics regarding the socioeconomic characteristics of vegetable sellers are presented in Table 1. One-way ANOVA was employed to test the difference in socioeconomic characteristics between carrot and cabbage sellers covered by this study. The comparison of socioeconomic characteristics between cabbage and carrot sellers both Chi-square-test and t-test are statistically significant except for gender and seller categories. The results indicate that carrot and cabbage sellers mostly differ in education levels, vegetable selling experience, source of investment, range of loans and outstanding amounts. Table 1 presents the socioeconomic characteristics of sellers of cabbages and carrots at local, regional and national markets.

Surveys were gathered from 90 vegetable sellers, including middlemen, traders, wholesalers and retailers with an average vegetable selling experience of 5-10 years. The result proved that most vegetable sellers interviewed were women $(64.71 \%$ of carrot sellers and $76.92 \%$ of cabbage sellers), and that the majority of respondents $(66.67 \%)$ were retailers. This is contrary to findings by Haruna et al. (2012) that $88 \%$ and $12 \%$ of vegetable sellers in Bauchi state were male and female, respectively (Haruna et al., 2012). Around 80\% of vegetable sellers sold carrots and vegetables every day and relied on financial support from personal funds (53.85\%). Approximately $46.15 \%$ used resources borrowed from banks and relatives; only $26.67 \%$ used the total amount of loan in vegetable marketing. This is supported by Aditto (2011) who found that the agricultural sellers in Thai rural areas lacked investment funds due to credit accessibility barriers (Aditto, 2011).

The statistics for the quantities sold and prices charged by wholesalers, traders and retailers active in local, regional, and national markets are presented in Table 2. The resulting lagged supply response to price changes causes cyclical adjustments that add an extra degree of variability to carrot and cabbage markets. The market value of carrots and cabbages tends to be higher from February to June, with a maximum price of RWF 350 per $\mathrm{kg}$ for carrots and RWF 150 per kg for cabbages produced in Rubavu district for wholesale and traders. The vegetable output in the volcanic region with no irrigation practices varies from one period to another because of natural shocks such as weather, pests and diseases. Usually, price elasticity of demand is relatively low; the seasonal productivity of vegetables suggests the same is true for the elasticity of supply, at least in the short run.

Upon harvesting, carrots are immediately packed in 100-kg bags (filled above the ends of bags). Cabbages are harvested, immediately loaded on trucks and supplied to regional and national markets, especially including Nyabugogo, Kimisagara and Kimironko. Only a small volume of low-quality graded vegetables is sold locally. Generally, the wholesaling activity takes place during early trading hours, from 5:00 AM to 9:00 AM, 
Kubwimana, J. J. (2020). Risk analysis of vegetables marketing in Rwanda. A case of carrots and cabbages produced in Northern Province, Rubavu District and supplied across the country. J. Agribus. Rural Dev., 2(56), 183-200. http://dx.doi.org/10.17306/ J.JARD.2020.01326

Table 1. Carrot and cabbages sellers' socioeconomic characteristics

\begin{tabular}{|c|c|c|c|c|c|c|c|}
\hline \multirow{3}{*}{ Variables } & \multicolumn{4}{|c|}{ Vegetable type } & \multirow{2}{*}{\multicolumn{2}{|c|}{ Overall $\mathrm{N}=90$}} & \multirow{3}{*}{ p-value } \\
\hline & \multicolumn{2}{|c|}{ Carrots $(n=51)$} & \multicolumn{2}{|c|}{ Cabbages $(\mathrm{n}=39)$} & & & \\
\hline & frequency & $\%$ & frequency & $\%$ & frequency & $\%$ & \\
\hline \multicolumn{8}{|l|}{ Gender } \\
\hline Male & 18 & 35.29 & 9 & 23.08 & 27 & 30 & 0.210 \\
\hline Female & 33 & 64.71 & 30 & 76.92 & 63 & 70 & \\
\hline \multicolumn{8}{|l|}{ Seller category } \\
\hline Wholesale or supply & 18 & 35.29 & 12 & 30.77 & 30 & 33.33 & \\
\hline Retailers & 33 & 64.71 & 27 & 69.23 & 60 & 66.67 & 0.652 \\
\hline \multicolumn{8}{|l|}{ Highest education } \\
\hline No education & 6 & 11.76 & 3 & 7.69 & 9 & 10 & \\
\hline Primary & 27 & 52.94 & 24 & 61.54 & 51 & 56.67 & $0.013 * *$ \\
\hline Secondary & 3 & 5.88 & 9 & 23.08 & 12 & 13.33 & \\
\hline Vocational training & 15 & 29.41 & 3 & 7.69 & 18 & 20.00 & \\
\hline \multicolumn{8}{|l|}{ Vegetable selling experience } \\
\hline$\leq 5$ years & 21 & 41.18 & 12 & 30.77 & 33 & 36.66 & \\
\hline $5-10$ years & 21 & 41.18 & 21 & 53.85 & 42 & 46.67 & $0.047 * *$ \\
\hline$<10$ years & 9 & 17.65 & 6 & 15.38 & 15 & 16.67 & \\
\hline \multicolumn{8}{|l|}{ Sources of investment } \\
\hline Borrowed from UNGUKA bank & 6 & 11.76 & 0 & 0.00 & 6 & 6.677 & \\
\hline Borrowed from URWEGO bank & 3 & 5.88 & 6 & 15.38 & 9 & 10 & $0.086^{*}$ \\
\hline Borrowed from relatives & 15 & 29.41 & 12 & 30.77 & 12 & 30 & \\
\hline Personal funds & 27 & 52.94 & 21 & 53.85 & 21 & 53.33 & \\
\hline \multicolumn{8}{|l|}{ Term of the loan } \\
\hline Less than 1 year & 18 & 66.67 & 15 & 83.33 & 33 & 73.33 & \\
\hline $2-3$ years & 9 & 33.33 & 3 & 16.67 & 12 & 26.67 & $0.099 *$ \\
\hline \multicolumn{8}{|l|}{ Outstanding loan } \\
\hline Fully repaid & 18 & 66.67 & 15 & 83.33 & 33 & 73.33 & \\
\hline$<$ RWF 100,000 & 9 & 33.33 & 3 & 16.67 & 12 & 26.67 & $0.099 *$ \\
\hline \multicolumn{8}{|c|}{ Frequency of lending in vegetable marketing } \\
\hline $100 \%$ & 12 & 44.44 & 0 & 0.00 & 12 & 26.67 & \\
\hline $90 \%$ & 6 & 22.22 & 0 & 0.00 & 6 & 13.03 & $0.000 * * *$ \\
\hline $80 \%$ & 9 & 33.33 & 18 & 100 & 27 & 60.0 & \\
\hline \multicolumn{8}{|l|}{ Frequency of selling vegetables } \\
\hline Every day & 42 & 82.35 & 30 & 76.92 & 72 & 80 & \\
\hline Once a week & 6 & 11.76 & 0 & 0.00 & 6 & 6.67 & $0.000 * * *$ \\
\hline Seasonally & 3 & 5.88 & 9 & 23.08 & 12 & 13.33 & \\
\hline \multicolumn{8}{|l|}{ Monthly net income } \\
\hline Less than 100,000 & 9 & 17.65 & 24 & 61.544 & 33 & 36.67 & \\
\hline $100,000-250,000$ & 21 & 41.18 & 3 & 7.69 & 24 & 26.67 & $0.000 * * *$ \\
\hline $250,000-500,000$ & 3 & 5.88 & 9 & 23.08 & 12 & 13.33 & \\
\hline Above 500,000 & 18 & 35.29 & 3 & 7.69 & 21 & 23.33 & \\
\hline
\end{tabular}

*significant at $10 \%$, *significant at $5 \%, * * *$ significant at $1 \%$.

The differences between vegetable sellers' characteristics were tested with independent t-test and chi-square.

Source: field survey, 2018. 
Kubwimana, J. J. (2020). Risk analysis of vegetables marketing in Rwanda. A case of carrots and cabbages produced in Northern Province, Rubavu District and supplied across the country. J. Agribus. Rural Dev., 2(56), 183-200. http://dx.doi.org/10.17306/ J.JARD.2020.01326

Table 2. Fluctuation of carrot and cabbage prices in the Rwandan market

\begin{tabular}{|c|c|c|c|c|c|c|c|c|c|c|c|}
\hline \multirow[b]{2}{*}{ Month } & \multirow[b]{2}{*}{ Crops } & \multicolumn{5}{|c|}{$\begin{array}{l}\text { Average quantity sold per person } \\
\quad \text { (wholesale, } \mathrm{N}=51 \text { ) }\end{array}$} & \multicolumn{5}{|c|}{$\begin{array}{l}\text { Average quantity sold per person } \\
\text { (retail, } \mathrm{N}=39 \text { ) }\end{array}$} \\
\hline & & $\begin{array}{c}\text { mean } \\
\text { qty sold }\end{array}$ & $\begin{array}{l}\text { qty of } \\
\text { losses }\end{array}$ & $\begin{array}{l}\text { monthly } \\
\text { price }\end{array}$ & price SD & $\begin{array}{c}\text { price } \\
\text { p-value }\end{array}$ & $\begin{array}{l}\text { mean } \\
\text { daily qty } \\
\text { sold }\end{array}$ & $\begin{array}{l}\text { qty of } \\
\text { losses }\end{array}$ & $\begin{array}{c}\text { monthly } \\
\text { price }\end{array}$ & $\begin{array}{l}\text { price } \\
\text { SD }\end{array}$ & $\begin{array}{c}\text { price } \\
\text { p-value }\end{array}$ \\
\hline \multirow[t]{2}{*}{ January } & Carrots & 9375 & 125 & 180.6 & 24.61 & $0.0019 * *$ & 200 & 10 & 239.1 & 71.07 & $0.037 * *$ \\
\hline & Cabbages & 7200 & 250 & 150 & 0 & & 150 & 15 & 133.3 & 37.21 & \\
\hline \multirow[t]{2}{*}{ February } & Carrots & 9350 & 125 & 169.4 & 34.22 & $0.0863 *$ & 184 & 10 & 280.9 & 89.13 & $0.000 * * *$ \\
\hline & Cabbages & 7200 & 125 & 150 & 0 & & 150 & 15 & 140 & 49.69 & \\
\hline \multirow[t]{2}{*}{ March } & Carrots & 9000 & 108 & 169.4 & 17.15 & $0.0039 * *$ & 181.25 & 6.66 & 299.5 & 73.71 & $0.000 * * *$ \\
\hline & Cabbages & 6000 & 250 & 150 & 0 & & 150 & 15 & 176.7 & 68.27 & \\
\hline \multirow[t]{2}{*}{ April } & Carrots & 9250 & 100 & 164.2 & 16.42 & $0.0033 * *$ & 176.66 & 6,66 & 216.2 & 42.5 & $0.000 * * *$ \\
\hline & Cabbages & 7000 & 233 & 145 & 5 & & 143.75 & 15 & 154.4 & 27.64 & \\
\hline \multirow[t]{2}{*}{ May } & Carrots & 9200 & 100 & 162.5 & 18.22 & $0.002 * *$ & 176.66 & 5 & 217.4 & 39.95 & $0.000 * * *$ \\
\hline & Cabbages & 7200 & 208 & 140 & 0 & & 140 & 10 & 159.4 & 24.31 & \\
\hline \multirow[t]{2}{*}{ June } & Carrots & 9200 & 100 & 154.2 & 19.19 & $0.0017 * *$ & 165.42 & 5 & 286.4 & 76.18 & $0.000 * * *$ \\
\hline & Cabbages & 6800 & 208 & 130 & 0 & & 133.75 & 10 & 170.5 & 44.45 & \\
\hline \multirow[t]{2}{*}{ July } & Carrots & 9000 & 80 & 148.3 & 16.74 & $0.005^{* *}$ & 158.33 & 5 & 305.7 & 65.51 & $0.000 * * *$ \\
\hline & Cabbages & 6400 & 125 & 130 & 0 & & 131.25 & 10 & 195 & 58.06 & \\
\hline \multirow[t]{2}{*}{ August } & Carrots & 8486 & 80 & 148.3 & 16.73 & $0.005^{* *}$ & 158.33 & 5 & 335.7 & 79.52 & $0.000 * * *$ \\
\hline & Cabbages & 6300 & 125 & 130 & 0 & & 13125 & 10 & 238.9 & 52.50 & \\
\hline \multirow[t]{2}{*}{ September } & Carrots & 8486 & 80 & 146.7 & 18.58 & $0.003 * *$ & 160.41 & 6.25 & 319.1 & 89.99 & $0.000 * * *$ \\
\hline & Cabbages & 6000 & 125 & 125 & 5.47 & & 126.65 & 10 & 227.8 & 42.36 & \\
\hline \multirow[t]{2}{*}{ October } & Carrots & 8486 & 100 & 143.8 & 21.45 & $0.0044 * *$ & 160.41 & 7,91 & 290.5 & 68.89 & $0.000 * * *$ \\
\hline & Cabbages & 5600 & 125 & 120 & 0 & & 120 & 14.375 & 200 & 33.96 & \\
\hline \multirow[t]{2}{*}{ November } & Carrots & 8857 & 100 & 138.3 & 14.76 & $0.0019 * *$ & 150 & 6.66 & 264.28 & 47.80 & $0.000 * * *$ \\
\hline & Cabbages & 5400 & 125 & 120 & 0 & & 120 & 14.375 & 200 & 35.35 & \\
\hline \multirow[t]{2}{*}{ December } & Carrots & 8715 & 100 & 138.3 & 14.76 & $0.0019 * *$ & 150 & 5,416 & 280.9 & 48.67 & $0.000 * * *$ \\
\hline & Cabbages & 6000 & 125 & 120 & 0 & & 120 & 11,25 & 211.1 & 54.64 & \\
\hline
\end{tabular}

Legend: *significant at $10 \%,{ }^{*}$ significant at $5 \%, * * *$ significant at $1 \%$.

The differences for quantities purchased, supplied and lost were tested with independent t-test and chi-square. The quantities were estimated in kilograms (kg) whereas costs and prices were estimated in Rwandan francs (RWF).

Source: field survey, 2018.

in the open air outside the markets. Usually, the vegetables are delivered directly from the back of small and medium-sized trucks. The wholesalers do not have access to cold storage or other value-adding services.
After 9:00 AM, the wholesalers must remove any unsold vegetables and find somewhere to store it until the following day. Often, it remains in the truck parked at roadside, leading to high losses. According to Youri et 
Kubwimana, J. J. (2020). Risk analysis of vegetables marketing in Rwanda. A case of carrots and cabbages produced in Northern Province, Rubavu District and supplied across the country. J. Agribus. Rural Dev., 2(56), 183-200. http://dx.doi.org/10.17306/ J.JARD.2020.01326

al. (2016), unsold vegetables are sold the following day at half price due to higher perishability. The markets are generally crowded, with limited room for expansion in the immediate vicinity (Youri et al., 2016). The highest retail prices are recorded from June to December, with the maximum price for carrots at RWF 335.7 per $\mathrm{kg}$ and RWF 238.9 per $\mathrm{kg}$ of cabbage in June due to low production capacity in other regions across the country. These findings are supported by the results of Harakan and Murat (2012) who argued that the prices show a declining tendency during the first quarter of the year. They grow in April and decline in June because of open field growing and excess supply of vegetables (Harakan and Murat, 2012). Contrary to a study by Shrestha (2008) in Nepal, these results suggest that the middlemen sold vegetables to retailers with a $50 \%-60 \%$ margin above the farm-gate price. Generally, vegetable prices in Nepal go down from mid-June to August because this is a regular production period. Vegetables are usually removed from the plots at the end of July to leave place for other crops (Shrestha, 2008).

\section{Vegetable sellers' perceptions of risk sources and risk management strategies}

The perceived sources of risk and risk management strategies were measured using a five-point Likert scale. The means for each risk source and strategy were arranged into a ranking. The standard deviation (SD) and confidence interval were used to indicate the variation in the ratings. Also, the independent t-test was employed to compare the differences in mean scores between the results for carrot and cabbage farmers.
The marketing risk was highly associated with (1) low prices of seasonal products (a mean of $4.76 \pm 0.43$ ); (2) weak market channels (a mean of $4.71 \pm 0.46$ ); (4) poor logistics and market communications (a mean of $4.53 \pm 0.61)$; (3) poor product handling and packaging (a mean of $4.53 \pm 0.08$ ); (4) lack of storage (a mean of $4.53 \pm 0.61$ ); and (5) higher perishability (a mean of $4.52 \pm 0.61)$ in the case of carrot sellers. The results proved that the top five market risks recognized by cabbage sellers were: (1) lack of storage (a mean of $4.69 \pm 0.46)$; (2) poor logistics and communications (a mean of $4.69 \pm 0.47$ ); (3) poor product handling and packaging (a mean of $4.69 \pm 0.47$ ); (4) weak market channels (a mean of $4.53 \pm 0.50$ ); and (5) low prices of seasonal products (a mean of $4.31 \pm 0.43$ ), respectively. All of these risks are considered to be highly important among the vegetables marketers interviewed. The $\mathrm{SD}$ of both risk sources in each group was below one; this indicates that the vegetable marketers interviewed were consistent in identifying them (Meuwissen and Hardarker, 2001). In a study by Flaten et al. (2005), the higher marketing risks faced by fresh agricultural commodities consisted in price variability, changes in government support, increase in costs of operating inputs, injury, illness and deaths of sellers and change in consumer preferences, with a statistically significant mean value ( $<0.01$ and 0.05 , respectively) (Flaten et al., 2005). This is in consonance with a study conducted by Fakayode et al. (2012) which (based on the discriminant analysis and the Kruskal-Wallis one-way analysis of variance by ranks to test the risk attitude) revealed that perishability of produce (a mean of 531.95), low price of

Table 3. Ranking the perceptions of risk sources by carrot and cabbage sellers in Rwanda

\begin{tabular}{|c|c|c|c|c|c|c|c|c|c|}
\hline \multirow[b]{2}{*}{ Risk sources } & \multicolumn{4}{|c|}{ Carrots $(\mathrm{n}=51)$} & \multicolumn{4}{|c|}{ Cabbages $(\mathrm{n}=39)$} & \multirow[b]{2}{*}{ p-value } \\
\hline & mean & $\mathrm{SD}$ & $\begin{array}{l}95 \% \text { conf. } \\
\text { interval }\end{array}$ & rank & mean & SD & $\begin{array}{l}95 \% \text { conf. } \\
\text { interval }\end{array}$ & rank & \\
\hline 1 & 2 & 3 & 4 & 5 & 6 & 7 & 8 & 9 & 10 \\
\hline Low prices of seasonal products & 4.76 & 0.43 & $4.64-4.88$ & (1) & 4.31 & 0.43 & $4.07-4.54$ & (5) & $0.0002 * * *$ \\
\hline Weak market channels & 4.71 & 0.46 & $4.57-4.83$ & (2) & 4.53 & 0.50 & $4.37-4.70$ & (4) & $0.0523 *$ \\
\hline $\begin{array}{l}\text { Discriminating price systems based on producer } \\
\text { quality }\end{array}$ & 3.17 & 1.44 & $2.77-3.58$ & (11) & 3.77 & 1.33 & $3.34-4.20$ & (9) & 0.9759 \\
\hline $\begin{array}{l}\text { Risk of poor logistics and lack of } \\
\text { communications }\end{array}$ & 4.53 & 0.61 & $4.35-4.70$ & (3) & 4.69 & 0.47 & $4.54-4.84$ & (2) & 0.9148 \\
\hline
\end{tabular}


Kubwimana, J. J. (2020). Risk analysis of vegetables marketing in Rwanda. A case of carrots and cabbages produced in Northern Province, Rubavu District and supplied across the country. J. Agribus. Rural Dev., 2(56), 183-200. http://dx.doi.org/10.17306/ J.JARD.2020.01326

Table 3 cont.

\begin{tabular}{lccccccccc}
\hline \multicolumn{1}{c}{1} & 2 & 3 & 4 & 5 & 6 & 7 & 8 & 9 & 10 \\
\hline Selling delay & 3.06 & 1.22 & $2.71-3.40$ & $(13)$ & 3.38 & 1.35 & $2.95-3.82$ & $(14)$ & 0.8828 \\
Perishability & 4.52 & 0.61 & $4.35-4.70$ & $(5)$ & 4.69 & 0.47 & $4.54-4.84$ & $(2)$ & 0.9148 \\
Lack of transparency in marketing systems & 3.76 & 1.36 & $3.38-4.15$ & $(9)$ & 4.08 & 1.28 & $3.66-4.49$ & $(7)$ & 0.8634 \\
Seasonal lack of market & 3.06 & 1.36 & $2.67-3.44$ & $(14)$ & 3.46 & 1.35 & $3.02-3.90$ & $(12)$ & $0.0091^{* *}$ \\
Poor product handling and packaging & 4.53 & 0.08 & $4.36-4.70$ & $(3)$ & 4.69 & 0.47 & $4.36-4.70$ & $(3)$ & 0.9148 \\
Lack of market information & 4.29 & 0.90 & $4.04-4.55$ & $(7)$ & 3.92 & 1.15 & $3.54-4.29$ & $(8)$ & $0.0452^{* *}$ \\
Problems with hired labor and contracts & 2.70 & 1.28 & $2.34-3.07$ & $(15)$ & 2.54 & 1.71 & $1.98-3.09$ & $(15)$ & 0.2988 \\
Poor market linkages & 2.59 & 1.59 & $2.14-3.03$ & $(17)$ & 3.77 & 1.55 & $3.27-4.27$ & $(10)$ & 0.9997 \\
Risk posed by a poorly organized supply chain & 4.12 & 1.50 & $3.69-4.54$ & $(8)$ & 3.61 & 1.61 & $3.09-4.14$ & $(12)$ & $0.0661^{*}$ \\
Price response predictability & 3.35 & 1.25 & $3.00-3.70$ & $(10)$ & 3.46 & 1.35 & $3.02-3.900$ & $(13)$ & 0.6529 \\
Storage risk & 4.53 & 0.61 & $4.35-4.70$ & $(4)$ & 4.69 & 0.46 & $4.54-4.84$ & $(1)$ & 0.9148 \\
Exploitation by middlemen & 3.17 & 1.80 & $2.81-3.36$ & $(12)$ & 1.73 & 1.26 & $1.42-2.04$ & $(16)$ & $0.0000^{* * *}$ \\
Risk related to transportation & 2.70 & 1.02 & $2.42-2.99$ & $(16)$ & 3.61 & 0.85 & $2.34-2.88$ & $(10)$ & 0.3281 \\
Price fluctuation & 4.35 & 1.03 & $4.06-4.64$ & $(6)$ & 4.15 & 1.42 & $3.69-4.61$ & $(6)$ & 0.2223 \\
\hline
\end{tabular}

Legend: *significant at $10 \%,{ }^{*}$ significant at $5 \%, * * *$ significant at $1 \%$.

The differences between vegetable sellers' characteristics were tested with independent t-test and chi-square.

Source: field survey, 2018.

vegetable products (a mean of 507.57), and poor product handling and packaging (a mean of 422.89) were perceived as the highest sources of market risks while high marketing costs (a mean of 256.27), lack of markets to absorb production (a mean of 280.75) and lack of market information (a mean of 298.59) were the lowestranked sources of market risk as perceived by the vegetable sellers interviewed (Fakayode et al., 2012).

The tests of differences in perception of marketing risk associated with low prices of seasonal products, poor market channels, seasonal lack of market, lack of market information, less organized supply chains and greater exploitation by middlemen between vegetable sellers were statistically significant (at $p<0.01$ and 0.05 , respectively).

Table 4 summarizes the results of risk management measures implemented by carrot and cabbage sellers produced in the volcanic region.

For carrot sellers, risk management strategies perceived to be of greater importance were the use of forward contracts (a mean of $4.65 \pm 0.48$ ), obtaining market information (a mean of $4.53 \pm 0.86$ ), selling at low prices due to perishability (a mean of $4.17 \pm 0.71$ ), contractual arrangements (a mean of $3.88 \pm 0.84$ ) and maintaining good relationships with traders (a mean of $3.76 \pm 1.16$ ). As regards cabbage farmers, the top-ranked risk management strategies were the same as for carrots farmers but differed in the mean scores only. In contrast, Aditto identified spreading the sales over several periods, selecting crop and/or animal varieties with a low price variability, and obtaining market information as having higher scores (Aditto, 2011). The perceived importance of selling at low prices due to perishability and maintaining good relationships with traders was statistically significant among carrot and cabbage sellers (at $\mathrm{p}<0.01$ and 0.1 , respectively).

\section{Factor analysis}

This section discusses the results of the factor analysis of risk sources and risk management strategies. The test of internal consistency reliability of each factor was assessed, and a cut-off level of 0.4 was set for the factor loadings the inter-correlation among the original variables and the interpretation purposes of this research (Hair, 2006). The varimax orthogonal rotation was performed in compliance with all of these requirements. 
Kubwimana, J. J. (2020). Risk analysis of vegetables marketing in Rwanda. A case of carrots and cabbages produced in Northern Province, Rubavu District and supplied across the country. J. Agribus. Rural Dev., 2(56), 183-200. http://dx.doi.org/10.17306/ J.JARD.2020.01326

Table 4. Ranking of perceptions of risk management strategies by carrot and cabbage sellers in Rwanda

\begin{tabular}{|c|c|c|c|c|c|c|c|c|c|}
\hline \multirow[b]{2}{*}{ Marketing risk management strategies } & \multicolumn{4}{|c|}{ Carrots $(\mathrm{n}=51)$} & \multicolumn{4}{|c|}{ Cabbages $(\mathrm{n}=39)$} & \multirow[b]{2}{*}{ p-value } \\
\hline & mean & SD & $\begin{array}{l}95 \% \text { conf. } \\
\text { interval }\end{array}$ & rank & mean & SD & $\begin{array}{l}95 \% \text { conf. } \\
\text { interval }\end{array}$ & rank & \\
\hline Selling at low prices due to perishability & 4.17 & 0.71 & $3.97-4.38$ & (3) & 4.61 & 0.63 & $4.41-4.82$ & (2) & $0.0032 * * *$ \\
\hline Use of forward contracts & 4.65 & 0.48 & $4.51-4.78$ & (1) & 4.61 & 0.49 & $4.45-4.77$ & (1) & 0.3803 \\
\hline $\begin{array}{l}\text { Obtaining market information on forecasted } \\
\text { price trends }\end{array}$ & 4.53 & 0.86 & $4.29-4.77$ & $(2)$ & 4.31 & 0.92 & $4.01-4.61$ & (3) & 0.1212 \\
\hline Maintaining good relationships with traders & 3.76 & 1.16 & $3.43-4.09$ & $(5)$ & 3.38 & 1.09 & $3.03-3.74$ & (6) & $0.0603 *$ \\
\hline Spreading sales over several periods & 2.23 & 0.73 & $2.03-2.44$ & (9) & 2.69 & 0.61 & $2.49-2.89$ & $(8)$ & 0.9988 \\
\hline Formal approaches (formal savings and lending) & 2.76 & 1.17 & $2.43-3.09$ & $(8)$ & 3.15 & 1.53 & $2.66-3.65$ & (7) & 0.9120 \\
\hline Contractual arrangements & 3.88 & 0.84 & $3.65-4.12$ & (4) & 3.69 & 1.01 & $3.66-4.02$ & $(5)$ & 0.1656 \\
\hline Risk sharing & 3.53 & 1.21 & $3.19-3.87$ & (6) & 3.85 & 0.96 & $3.53-4.16$ & (4) & 0.9090 \\
\hline Selling across the country & 2.94 & 0.95 & $2.67-3.21$ & (7) & 2.61 & 0.94 & $2.31-2.92$ & (9) & $0.0537^{*}$ \\
\hline
\end{tabular}

Legend: $* * *$ p-value $<0.01, * *$ p-value $<0.05, *$ p-value $<0.1$.

The differences between vegetable sellers' characteristics were tested with independent t-test and chi-square.

Source: primary data, 2018.

The factor analysis grouped the 15 sources of risk variables recognized by vegetable sellers into 5 factors which explained almost $63.41 \%$ of variance, as shown in Table 5.

Factor one (F1) had six significant loading variables, factors 2, 3 had 4 variables each, and factors $4-5$ had 2 variables each. The Cronbach's alpha values for factors $\mathrm{F} 1-5$ varied in the range of 0.638 to 0.884 , which demonstrates adequate reliability among those factors. Contrarily, a study on the Syrian pistachio market by Göttingen (2014) included a factor analysis based on 4 factors, namely F1 (production), F2 (farm business environment), F3 (market), F4 (input prices) and F5 (pistachio expansibility); compared to this study, the Cronbach's alpha test of internal consistency reliability resulted in low values, varying in the range of 0.61 to 0.73 (Göttingen, 2014).

In this study, factor one was labeled as "market price" because of the relatively high loadings on the sources of risk variables related to market issues, especially including higher marketing costs, lack of discrimination marketing systems, lack of transparency in the marketing system, seasonal lack of market, lack of market information and predictability of price response. The test of internal consistency reliability varied in the range of 0.448 to 0.835 . In the study conducted by Göttingen (2014), that interval was 0.42-0.87 (Göttingen, 2014).

Factor two (F2), named "seasonal productivity," has a significant loading of low prices of seasonal products, selling delay, perishability and great exploitation by middlemen, with the test of internal consistency reliability varying in the range of 0.797 to 0.88 . Factor three (F3), labeled as "economic and political aspects," was highly associated with poor logistics and communications, poor handling and packaging of vegetables, storage risk and transportation costs, and had a higher value of the internal consistency test $(0.707-$ 0.860 ). Factor four (F4) can be interpreted as a "personal business environment" because of higher factor loadings of "poor market linkages and poor linkage of supply chains." Finally, factor five (F5) is related to "poor logistics and communications and storage risk" and is classified as "infrastructure facilities." In the study conducted by Göttingen (2014), the farm business factor was highly associated with climate factors $(0.83)$ and theft $(0.60)$, whereas the market price factor was strictly related to product competitiveness of neighboring countries $(0.78)$, price fluctuation $(0.77)$, brokers' dominance $(0.74)$ and price decrease $(0.42)$ (Göttingen, 2014). 
Kubwimana, J. J. (2020). Risk analysis of vegetables marketing in Rwanda. A case of carrots and cabbages produced in Northern Province, Rubavu District and supplied across the country. J. Agribus. Rural Dev., 2(56), 183-200. http://dx.doi.org/10.17306/ J.JARD.2020.01326

Table 5. Varimax rotation of risk sources for vegetable sellers in Rwanda

\begin{tabular}{|c|c|c|c|c|c|c|}
\hline \multirow{2}{*}{ Risk sources } & \multicolumn{5}{|c|}{ Factors $(\mathrm{n}=90)$} & \multirow{2}{*}{$\begin{array}{c}\text { Commu- } \\
\text { nality }\end{array}$} \\
\hline & F1 & $\mathrm{F} 2$ & F3 & $\mathrm{F} 4$ & F5 & \\
\hline High marketing costs & 0.835 & 0.129 & 0.164 & 0.076 & 0.026 & 0.747 \\
\hline $\begin{array}{l}\text { Lack of discriminating pricing systems } \\
\text { based on producer quality and grade }\end{array}$ & 0.761 & 0.048 & 0.258 & 0.139 & 0.034 & 0.713 \\
\hline Lack of transparency in marketing systems & 0.690 & 0.108 & 0.244 & 0.022 & 0.007 & 0.549 \\
\hline Seasonal lack of market to absorb vegetables & 0.662 & 0.279 & 0.173 & 0.062 & 0.289 & 0.634 \\
\hline Lack of market information & 0.553 & 0.243 & 0.226 & 0.327 & 121 & 0.606 \\
\hline Price response predictability & 0.448 & 0.043 & 0.386 & 0.350 & 0.193 & 0.690 \\
\hline Low prices of seasonal products & 0.047 & 0.888 & 0.186 & 0.092 & 0.032 & 0.882 \\
\hline Selling delay & 0.065 & 0.846 & 0.257 & 0.014 & 0.067 & 0.791 \\
\hline High perishability of vegetables & 0.157 & 0.854 & 0.085 & 0.165 & 0.044 & 0.786 \\
\hline Exploitation by middlemen & 0.045 & 0.797 & 0.032 & 0.031 & 0.135 & 0.798 \\
\hline Risk of poor logistics and lack of communications & 0.237 & 0.262 & 0.749 & 0.260 & 0.809 & 0.761 \\
\hline Poor product handling and packaging & 0.343 & 0.348 & 0.707 & 0.055 & 0.146 & 0.764 \\
\hline Storage risk & 0.356 & 0.212 & 0.860 & 0.175 & 0.697 & 0.561 \\
\hline Transportation costs & 0.056 & 0.043 & 0.809 & 0.181 & 0.096 & 0.717 \\
\hline Poor market linkages & 0.078 & 0.113 & 0.049 & 0.798 & 0.145 & 0.681 \\
\hline Risk posed by a poorly organized supply chain & 0.047 & 0.014 & 0.007 & 0.880 & 0.069 & 0.806 \\
\hline Eigenvalues & 5.28 & 2.18 & 1.45 & 1.11 & 1.03 & \\
\hline$\%$ of total variance explained & 29.35 & 12.13 & 8.05 & 6.17 & 5.71 & \\
\hline Cumulative $\%$ of variance explained & 29.35 & 43.48 & 51.53 & 57.7 & 63.41 & \\
\hline Cronbach's alpha & 0.748 & 0.884 & 0.766 & 0.639 & 0.766 & \\
\hline Number of variables & 6 & 4 & 4 & 2 & 2 & \\
\hline
\end{tabular}

$* * *$ p-value $<0.01, * *$ p-value $<0.05, *$ p-value $<0.1$.

F1 - market price, F2 - seasonal productivity, F3 - economic and political aspects, F4 - personal business environment, F5 - infrastructure facilities, F6 - financial situation.

The differences between vegetable sellers' characteristics were tested with independent t-test and chi-square.

Source: primary data, 2018.

\section{Multivariate regression of components of risk sources and risk strategies with vegetable sellers' characteristics}

The multiple regression analysis was employed to investigate the relationship between the vegetable sellers' socioeconomic characteristics and the perceptions of risk source and risk management strategy components obtained from the factor analysis. The summated scales of each source of risk and risk strategy factors of each category of vegetable sellers were summed up and averaged based on relevant variables in each factor structure and their internal consistency (Aditto, 2011). Each of the models 1-4 included at least 1 socioeconomic characteristic statistically significant at $5 \%(\mathrm{p}<0.05)$.

The goodness-of-fit coefficients were rather low for all models, except for models 2 and 5 which both had 
Kubwimana, J. J. (2020). Risk analysis of vegetables marketing in Rwanda. A case of carrots and cabbages produced in Northern Province, Rubavu District and supplied across the country. J. Agribus. Rural Dev., 2(56), 183-200. http://dx.doi.org/10.17306/ J.JARD.2020.01326

Table 6. Multivariate regression of components of risk sources and vegetable sellers' characteristics

\begin{tabular}{lcccccc}
\hline \multirow{2}{*}{\multicolumn{1}{c}{ Independent variables }} & \multicolumn{5}{c}{ Components of marketing risks sources (n=90) } \\
\cline { 2 - 6 } & $\mathrm{F} 1$ & $\mathrm{~F} 2$ & $\mathrm{~F} 3$ & $\mathrm{~F} 4$ & $\mathrm{~F} 5$ & $\mathrm{~F} 6$ \\
\hline Gender $^{\mathrm{a}}$ & 0.0388 & -0.2406 & $-0.5715^{* *}$ & 0.1926 & -0.2406 & -0.0747 \\
Seller category $^{\mathrm{b}}$ & -0.2027 & -0.1432 & -0.0597 & -0.1836 & -0.1432 & 0.0788 \\
Sellers' education level $^{\mathrm{c}}$ & -0.0025 & $0.8153^{* * *}$ & -0.0907 & 0.0513 & $0.8153^{* * *}$ & $-0.4556^{* *}$ \\
Vegetable selling experience $^{\mathrm{d}}$ & 0.2908 & 0.3969 & $0.9021^{* * *}$ & -0.2490 & $0.3969^{*}$ & 0.1579 \\
Selling rate $^{\mathrm{e}}$ & 0.0628 & $0.0103^{*}$ & $-0.2872^{*}$ & 0.2972 & 0.0103 & -0.0828 \\
Sources of finance $^{\mathrm{f}}$ & $-0.5151^{* *}$ & $-0.6064^{* * *}$ & $-0.1555^{* *}$ & -0.0860 & $-0.6064 * * *$ & 0.3846 \\
Monthly net income $^{\mathrm{g}}$ & -0.0511 & $-0.3171^{* *}$ & -0.1280 & -0.6370 & $-0.3171^{* *}$ & 0.2032 \\
Constant $^{*}$ & $0.9461^{* * *}$ & $0.5687^{* * *}$ & $0.9019 * * *$ & $0.5337^{* * *}$ & $-0.3171^{* *}$ & 0.3171 \\
$\mathrm{R}^{2}$ & 0.0719 & $0.4409^{* * *}$ & $0.1542^{* *}$ & 0.1004 & $0.4409^{* * *}$ & 0.0869 \\
\hline
\end{tabular}

F1 - market price management, F2 - seasonal productivity, F3 - economic and political policy, F4 - personal business environment, F5 - infrastructure facilities, F6 - financial management.

$* * *$ p-value $<0.01, * *$ p-value $<0.05, *$ p-value $<0.1$.

The differences between vegetable sellers' characteristics were tested with independent t-test and chi-square.

${ }^{\mathrm{a}} 1$ if the vegetable seller is male, 0 if female.

${ }^{\mathrm{b}} 1$ if the vegetable seller is a wholesaler, middlemen or trader, 0 if the vegetable seller is a retailer.

${ }^{\mathrm{c}} 1$ if the vegetable seller has an education higher than primary, 0 otherwise.

${ }^{\mathrm{d}} 1$ if the vegetable seller's experience is greater than 5 years, 0 otherwise.

${ }^{\mathrm{e}} 1$ if the marketer sells every day, 0 otherwise.

${ }^{\mathrm{f}} 1$ if the marketer uses personal funds, 0 if otherwise.

${ }^{g} 1$ if the vegetable seller has a monthly income greater than RWF 250,000, 0 if otherwise.

Source: primary data, 2018.

a coefficient of determination $\left(\mathrm{R}^{2}\right)$ of $44.09 \%$. The result of the $\mathrm{R}^{2}$ value seems to be greater but is in line with previous studies. The $\mathrm{R}^{2}$ value recorded by Göttingen (2014) was 0.26 and 0.24 for Syrian farmer and marketer groups, respectively. This value was 0.12 in a study conducted among organic and conventional dairy farmers in Norway (Flaten et al., 2005; Göttingen, 2014). Risks related to the market price, seasonal productivity, economic and political aspects and infrastructure facilities were perceived as highly important by vegetable sellers who used investment funds borrowed from banks and relatives. This suggests that vegetable sellers who rely on loans are more likely to pay attention to changes in market prices, product variability, market policy changes and infrastructure facilities.

The experience in vegetable selling is positively related to the perception of risks involved in 'economic and political aspects, and infrastructure facilities.' However, gender and the vegetable selling rate exhibited a negative relationship with this source of risk. This result suggests that highly experienced vegetable sellers who sell vegetables every day and male vegetable sellers tended to perceive the 'economic and political aspects, and infrastructure facilities' as a highly important source of risks. Educated vegetable sellers were 0.82 less likely to be affected by economic and political aspects and by infrastructure facilities. This result was similar to the findings from a study conducted by Aditto (2008) in Thailand which pointed out that highest education levels were positively related to yields and product prices, and to economic and political aspects. Educated vegetable producers and sellers were 0.68 and 0.123 less likely to be affected by political and economic aspects, and product price risks, respectively, compared to their uneducated peers (Aditto, 2011).

Vegetable sellers' education levels are positively related to 'seasonal productivity and infrastructure facilities' risk perceptions. This suggests that better educated 
Kubwimana, J. J. (2020). Risk analysis of vegetables marketing in Rwanda. A case of carrots and cabbages produced in Northern Province, Rubavu District and supplied across the country. J. Agribus. Rural Dev., 2(56), 183-200. http://dx.doi.org/10.17306/ J.JARD.2020.01326

vegetable sellers perceived these sources of risk to be significantly more important in marketing. The probable reason is that better educated vegetable sellers found seasonal productivity and infrastructure facilities to be the main factors which indirectly affect the vegetable business. This is similar to what was established by Gietz et al. (2015), namely that market risks are limited for Rwandan food crop producers, generally because most markets are local, the prices fluctuate seasonally and in direct response to supply and demand. As such, price fluctuations do not constitute a risk but are rather caused by constraints. Domestic markets for commodities seem to be well integrated, with limited disparities in terms of fluctuations (Gietz et al., 2015).

Table 7 summarizes the multiple regression models of the components of risk management strategies and socioeconomic variables for carrot and cabbage sellers. The correlation coefficients were generally low in all models, except for model one where the coefficient of correlation accounted for nearly $59 \%$ of variation in the dependent variable. The $\mathrm{R}^{2}$ value recorded by Göttingen
(2014) was $36 \%$ of total variance related to risk management factors (Göttingen, 2014). The models 1-3 are statically significant at $1 \%$ and $5 \%(\mathrm{p}<0.01$ and $\mathrm{p}<0.05)$.

Education levels of vegetable sellers were positively related to 'financial management, and business diversification.' These relationships might be due to better educated people having a strong ability to analyze the business situation, an extensive knowledge of scarce resources and the ability to manage money rather than for illiteracy. Educated vegetable sellers were 0.47 and 0.38 less likely to adopt a business diversification strategy and exhibited better business management performance than their uneducated peers. This result was similar to what was found in a study conducted by Aditto (2008) in Thailand. According to him, better educated vegetable farmers and sellers were 0.258 and 0.16738 less likely to adopt a business diversification strategy and exhibited better business management performance than their uneducated peers (Aditto, 2011).

The vegetable selling experience was negatively related to 'marketing management' and positively related

Table 7. Multivariate regression of risk strategy components and vegetable sellers' characteristics

\begin{tabular}{lccc}
\hline \multirow{2}{*}{ Independent variables } & \multicolumn{2}{c}{ Components of production risks sources $(\mathrm{n}=90)$} \\
\cline { 2 - 4 } & $\mathrm{F} 1$ & $\mathrm{~F} 2$ & $\mathrm{~F} 3$ \\
\hline Gender $^{\mathrm{a}}$ & 0.0687 & -0.1164 & $-0.5918^{* * *}$ \\
Seller category $^{\mathrm{b}}$ & $-0.2257^{*}$ & 0.1415 & 0.0019 \\
Sellers' education level $^{\mathrm{c}}$ & 0.1766 & $0.4741^{* * *}$ & $0.3836^{* *}$ \\
Vegetable selling experience $^{\mathrm{d}}$ & $-0.6372^{* *}$ & 0.4609 & $0.7339^{* *}$ \\
Selling rate $^{\mathrm{e}}$ & -0.0029 & $-0.1885^{*}$ & 0.0820 \\
Sources of finance $^{\mathrm{f}}$ & 0.3066 & $-0.7214^{* * *}$ & $-0.6254^{* * *}$ \\
Monthly net income $^{\mathrm{g}}$ & -0.0511 & $-0.4867^{* * *}$ & $-0.5099^{* * *}$ \\
Constant $^{2}$ & $0.1858^{* * *}$ & $0.9225^{* * *}$ & $1.1529^{* * *}$ \\
$\mathrm{R}^{2}$ & $0.5899^{* *}$ & $0.2241^{* * *}$ & $0.2531^{* * *}$ \\
\hline
\end{tabular}

F1: marketing management, F2: business diversification, F3: financial management. Legend: *** p-value $<0.01, * *$ p-value $<0.05, *$ p-value $<0.1$. The differences between vegetable sellers' characteristics were tested with independent t-test and chi-square.

( ${ }^{\mathrm{b}} 1$ if the vegetable seller is a wholesaler, middlemen or trader, 0 if the vegetable seller is a retailer), ( ${ }^{\mathrm{a}} 1$ if the vegetable seller is male, 0 if female), ( ${ }^{c} 1$ if the vegetable seller has an education higher than primary, 0 otherwise), ( $1^{\mathrm{e}}$ if the marketer sells every day, 0 otherwise), ( ${ }^{\mathrm{f}} 1$ if the marketer uses personal funds, 0 if otherwise) ( ${ }^{\mathrm{d}} 1$ if the vegetable seller's experience is greater than 5 years, 0 otherwise) ( ${ }^{\mathrm{g}} 1$ if the vegetable seller has a monthly income greater than RWF 250,000, 0 if otherwise)

Source: primary data, 2018. 
Kubwimana, J. J. (2020). Risk analysis of vegetables marketing in Rwanda. A case of carrots and cabbages produced in Northern Province, Rubavu District and supplied across the country. J. Agribus. Rural Dev., 2(56), 183-200. http://dx.doi.org/10.17306/ J.JARD.2020.01326

to 'financial management' factors. This implied that vegetable sellers with more than 5 years' selling experience perceived marketing management strategy as having a greater importance. In contrast, those who had less than 5 years of experience perceived financial management focus as the best strategy to overcome the market risk factors. For specialized and large producers, market risks could reflect the negative impacts of the absence of a specialist market while also being the unexpected state probation of country export in some years due to economic and political change (Ali, 2008; Göttingen, 2014). Agricultural commodity sellers with greater selling experience perceived business diversification strategies to be highly important. It should be noted that those who had less experience were ones of the constraints to diversification. Marketers with a short experience have a limited ability to diversify their activities (Ahmad, et al., 2003).

Both the sources of investment and monthly net incomes were negatively related to 'marketing management and 'business diversification' factors. Those who accessed bank loans, just as those who earned a monthly income below RWF 250,000, perceived managing seasonal productivity and analyzing the changes to economic policies as highly important strategies in overcoming the marketing risk. Sellers of agricultural commodities who have their own will and those who derive incomes from non-agricultural sources were less worried about the risks associated with an unfavorable agricultural season, business environment and economic policy changes (Göttingen, 2014).

In contrast, Gietz, A., et al. (2015) proposed improved market information as the best strategy to cope with market risks. An improved market information system can provide accurate, timely and transparent information about production and stocks, traders' flows and prices in different markets to aid in the management of price volatility in domestic, regional, and international markets of vegetables produced in Rwanda (Gietz et al., 2015).

\section{CONCLUSION AND RECOMMENDATION}

Generally, the agricultural production environment, and vegetable marketing in particular, are risky a business. Vegetable sellers exactly know the impacts of risks on their business but lack precise measures to overcome those risks because some of them are unable to cope with it. Therefore, to assist vegetable sellers in earning stable returns, it is better to help them understand the sources of risks and risk reduction strategies in the vegetable marketing system.

Therefore, the objectives of this study was to measure and analyze the major sources of risk and risk management in vegetable marketing, based on perceptions of vegetable sellers who typically sell cabbages and carrots produced in the volcanic region of the Northern Province of Rwanda. The result from the perceptions sources of risk was ranked at different levels among the carrots and cabbage sellers. The market pricing situation proved that the price fluctuation risk due to perishability is perceived as the most important source of risks. Furthermore, such sources of risk as low prices of seasonal products, weak market channels, poor logistics and market communications, poor product handling and packaging, lack of storage and higher perishability were ranked high by all vegetable sellers.

The factor analysis found that the market price factor had a relatively high loading on the sources of risk variables related to market issues, especially including higher marketing costs, lack of discrimination marketing systems, lack of transparency in the marketing system, seasonal lack of market, lack of market information and predictability of price response.

Findings from the analysis of how risk management strategies are perceived indicate that the use of forward contracts, obtaining market information, selling at low prices due to perishability, contractual arrangements, and maintaining good relationships were important concerns (in that order of importance). Although the vegetable sellers' education levels were positively related to 'marketing management' and 'business diversification,' these relationships may be due to the fact that better educated people are able to analyze seasonal productivity and the economic and political situation. Vegetable sellers with more than 5 years of selling experience perceived the market price strategy as having a higher importance. In contrast, those who had less than 5 years' experience perceived the business diversification focus as the best strategy to overcome the market risk factors. While Rwandan vegetable marketers adopted various strategies, the most important among them were: using forward contracts, obtaining market information, selling at low prices due to perishability, making contractual arrangements, and maintaining good relationships with traders.

In this study, a large number of vegetable marketers indicated that no value was added to their products. 
Kubwimana, J. J. (2020). Risk analysis of vegetables marketing in Rwanda. A case of carrots and cabbages produced in Northern Province, Rubavu District and supplied across the country. J. Agribus. Rural Dev., 2(56), 183-200. http://dx.doi.org/10.17306/ J.JARD.2020.01326

Hence, they failed to access formal marketers. It is therefore recommended to provide vegetable marketers with support from the government and private entities to add value to their products, especially through processing and packaging, so the vegetable products may be stored over long periods even without cold room facilities.

Further, above the strategies adopted by vegetable sellers, the government of Rwanda should implement a vegetable pricing system mechanism designed to cope with the increase in vegetable prices on the market, to mitigate the volatility of vegetable prices, build vegetable storages facilities and restore the storage network system (crops and cold chain) spanning from vegetable farm gate to the main market, so as to allow vegetable sellers to supply their produce in line with market demand. It is also recommended to support the training initiatives which would enable the vegetable sellers to use formal risk management mechanisms such as marketing contracts to cope with downturns in commodity prices and price exploitation.

The government of Rwanda should operate pledging schemes for the major perishable commodities, especially vegetables. The purpose of this scheme would be to help vegetable marketers when market prices of their commodities fluctuate early in the harvesting season. Rwandan public policy institutions should discontinue their highly-interventional projects and encourage vegetable sellers to supply their products through futures contracts with vegetable growers and traders to reduce price risks and income volatility.

In the future, a comparative research needs to be performed to evaluate the risk factors associated with vegetable production among the irrigated and rain-fed vegetable farming systems in different agro-ecological zones in Rwanda. This is because the types of vegetables grown, weather and geographical conditions and production costs strongly differ between vegetable farmers in the whole country. Other methods, such as the observed economic behavior (OEB), risk aversion or stochastic models should be used in future research.

\section{LIMITATIONS OF THE STUDY}

There are several limitations in this research related to sample selection, data, and estimation technique: (1) the sample selection was performed among vegetable sellers who sold various categories of agricultural commodities; some of them may spend even 1 or 2 months without selling vegetable commodities. (2) The data collection process period was from January to March 2018; all vegetable sellers were asked to provide information on the previous year. However, some of them did not keep any financial records, and therefore had nowhere to look to remember some information. (3) No similar study has been conducted in Rwanda and not enough of them have been carried out in Africa. This is especially true for studies which employ the Likert-scale technique through a structured questionnaire. As a consequence, there is lack of broad empirical studies. (4) In this study, the regression analysis used cross-sectional data which exhibited lower $\mathrm{R}^{2}$ compared to time series data (Reisinger, 1997).

\section{ACKNOWLEDGEMENT}

The authors would like to thank the University of Rwanda for support provided throughout this research work.

\section{REFERENCES}

Aditto, S. (2011). Risk Analysis of Smallholder Farmers in Central and North-East Thailand. Lincoln Univeristy.

Ahmad, A., Isvilanonda, S. (2003). Rural Povert and agricultural diverisfication in Thailand. Department of Economics, Lund Univeristy.

Ahsan, D.A., Roth, E. (2010). Farmers' Perceived Risks and Risks Management Strategies in an Emerging Mussel Aquaculture Industry in Denmark. Mar. Res. Econ., 25(3), 309-323.

Ali, J., Kapoor, S.K. (2008). Farmers' Perception on Risks in Fruits and Vegetables Production: An Empirical Study of Uttar Pradesh. Agric. Econ. Res. Rev., 21, 317-326.

Almadani, M.I.N. (2014). Risk attitude, risk perceptions and risk management strategies: an empirical analysis of Syrian wheat-cotton and pistachio farmers. Georg-AugustUniversität Göttingen: Göttingen.

Coulibaly, O., Nouhoheflin, T., Aitchedji, C.C., Cherry, A.J., Adegbola, P. (2011). Consumers' perceptions and willingness to pay for organically grown vegetables. Int. J. Veg. Sci., 17(4), 349-362.

Cox, S., Flin, R. (1998). Safety Culture: Philosopher's Stone or Man of Straw? Work Stress., 12(3), 941-952.

DeVellis, R.F. (1991). Scale Development: Theory Application. Newbury Park, CA: Sage Publications, Social Research Methods Series.

Dijkxhoorn, Y., Saavedra, G., Judge, L.O. (2016). Horticulture and floriculture in Rwanda, Identification of focus 
Kubwimana, J. J. (2020). Risk analysis of vegetables marketing in Rwanda. A case of carrots and cabbages produced in Northern Province, Rubavu District and supplied across the country. J. Agribus. Rural Dev., 2(56), 183-200. http://dx.doi.org/10.17306/ J.JARD.2020.01326

areas for sector development. Wageningen: LEI Wageningen UR (Univeristy and Research Centre).

Dunn, J.W. (2002). Farm Level Risk Analysis for Kansas Farmers. Unpublished Doctoral Thesis, Kansas State Univeristy, Manhattan, Kansas.

Fakayode, S., Rahji, M., Adeniyi, S. (2012). Economic analysis of risks in fruit and vegetable farming in Osun state, Nigeria. Bangl. J. Agric. Res., 37(3), 473-491. https://doi. org/10.3329/bjar.v37i3.12125

FAO (2014). Youth and Agriculture: Key Chalenges and Concretes Solutions. Food and Agriculture Organization of United Nations (FAO) in Collaboration with the Technical Centre for Agricultural and Rural Cooperation and International Fund for the Agricultural Development (IFAD).

Flaten, O., Lien, G., Koesling, M., Valle, P.S., Ebbesvik, M. (2005). Comparing risk perception and risk management and conventional dairy farming: Empirical results from Norway. Liv. Prod. Sci., 95(1-2), 11-25.

Gietz, A., Mohinder, S.M., George, R., Diana, G., Kilara, S. (2015). Agricultural Sector Risk Assessment : A case of Rwanda. In World Bank Group Report Number96290-RW. Agriculture Global Practice Technical Assistance Paper.

Gujarati, D.N. (1995). Basic Econometrics. In: Statistics (3rd ed.). McGraw-Hill.

Hair, J.F. (2006). Multivariate Analysis (6th Edition). New Jersey: Pearson Prentice Hall.

Hair, J.F., Black, W.C., Babin, B.J., Anderson, R. (2010). Multivariate data analysis. Pearson Prentice Hall.

Harakan, E., Murat, Y. (2012). An Analysis of Tomato Prices at Wholesale Level in Turkey: An Application of SARIMA model. ResearchGate, 52-75.

Hardaker, J.B., Huirne, R.B.M., Anderson, J.R., Lien, G. (2004). Coping Agricultural Risk. Cambridge, MA: CABI Pub.

Haruna, U., Sani, M.H., Danwanka, H.A., Adejo, E. (2012). Economic Analysis of Fresh Tomatoes Markets in Baauchi Metropolis of Bauchi State, Nigeria.

Harvey, J., Erdos, G., Bolam, H., Cox, M.A., Kennedy, J.N., Gregory, D.T. (2002). An analysis of safety culture attitudes in a highly regulated environment. Work Stress., 16(1), 18-36.

Hossain, S., Mustapha, N.H.N., Chen, L. (2002). A quadratic application in farm planning under uncertainty. Int. J. Soc. Econ., 29(4), 282-298.

Jacobs, O. (2008). Market Development and Smallholder Farmers. A Selective Literature Survey. Background Paper for the "Second Economy Project", HSRC-CPEG.

Jari, B. (2009). Institutional and technical factors influencing agricultural marketing channel choices amongst smallholders and emerging farmers in the Kat River Valley. Doctoral Thesis. Alice: University of Fort Hare.
Kisaka-Lwayo, M., Obi, A. (2010). Risk Perceptions and Risk Management Strategy by Smallholders Farmers in Kwazulu-Natal Province, South Africa. Int. J. Agric. Manag., 1(3), 21-33.

Kohl, R.L., Uhl, J. L. (1985). Marketing of Agricultural product. New York: McMillian Publishing Company.

Kumar, R. (2005). Comprehensive Statistical Theory of Communications (Laxmi Publ).

Matsane, S.H., Oyekale, A.S. (2014). Factors affecting marketing of vegetables among small-scale farmers in mahikeng local municipality, North West Province, South Africa. Mediter. J. Soc. Sci., 5(20), 390-397. https://doi. org/10.5901/mjss.2014.v5n20p390

Meuwissen, M.P.M., Hardarker, J.B. (2001). Sources of Risk and Risk Management: An empirical analysis of Dutch Livestocks analysis. Lives. Prod. Sci., 69(1), 521-525.

MININFRA (2016). Environmental and Social Impact Assessment (ESIRA). Ministry of Infrastructure.

Mutungul, P.M., Ortmann, G.F. (2001). Transaction Costs and Marketing in the Communal Areas of Impendle and Swayimana, KwaZulu-Natal. Dev. South Afr., 18(30), 347-363.

NAEB (2014a). National Horticulture Policy and Strategic Implementation Plan.

NAEB (2014b). National Horticulture Policy and Strategic Implementation Plan.

Nunnally, J.C., Bernstein, I. (1994). Psychometric theory (3rd ed.). New York: MacMillan.

Nurah, K.G. (2000). Marketing strategy of organic products. Proceedings of the Agricultural Marketing Workshop, Sunyani, March 2000. GTZ-Ministry of Food and Agriculture (MoFA).

Nyikal, R.A., Kosura, W.O. (2005). Risk Preferences optimal enterprise combinations in Kahuro division of Muranga District, Kenya. Agriculture Economics, 32(2), 131-140.

Osei-Asare, Y.B. (2009). Status of Organic Agriculture in Ghana: A survey of Consumers, Producers, and Marketers. An FAO/GOAN/MOFA project on organic and fair trade exports from Africa.

Owusu, V., Anifori, M.O. (2012). Assessing consumer willingness to pay a premium for organic food product: Evidence from Ghana. Selected Paper prepared for presentation at the International Association of Agricultural Economists (IAAE) Triennial Conference, Foz do Iguaçu, Brazil, August. In Triennial Conference, Foz do Iguaçu, Brazil.

Pannell, D.J., Malcom, B., Kingwell, R.S. (2000). Are We Risking Too Much? Perspectives on Risk in Farm Modeling. Agric. Econ., 23(1), 69-79.

Parker, J.S., Wilson, R.S., Lejeune, J.T., Doohan, D. (2012). Including Growers in the "Food Safety" Conversation: Enhancing the Design and Implementation of Food Safety Programming Based on Farm and Marketing Needs of 
Kubwimana, J. J. (2020). Risk analysis of vegetables marketing in Rwanda. A case of carrots and cabbages produced in Northern Province, Rubavu District and supplied across the country. J. Agribus. Rural Dev., 2(56), 183-200. http://dx.doi.org/10.17306/ J.JARD.2020.01326

Fresh Fruit and Vegetable Producer. Agric. Human Val., 29(3), 3003-3319.

Peter, J.P. (1979). Reliability: A review of Psychometric basis and recent marketing practices. J. Market. Res., 16(1), 6-17.

Reisinger, H. (1997). The impact of research designs on R2 in linear regression model: An explenatory meta-analysis. J. Empir. General. Market. Sci., 2(1), 1-12.

Scheaffer, R.L., Mendenhall, W., Ott., L. (2006). Elementary Survey Sampling (6th Edition). Belmont, California: Thomson Books/Cole.

Shadbolt, N.M., Martin, S.K. (2005). Farm Management in New Zeland. Oxford: Oxford Univeristy Press.

Shaughnessy, J.J., Zechmeister, E.B, Zechmeister, J.S. (2003). Research methods in psychology (6th ed.). McGraw-Hill.

Shrestha, B. (2008). Off-Season Vegetables Marketing Channels of Small Growers: A Case of Yampaphant, Tanahun.
Nepal Fulfillment of the Requirements for the Degree of Master of Development Specialization-International Agriculture (IA).

Sirven, P., Gotanegre, J.F., Prioul, C. (1974). Geographie du Rwanda. (ed. A)

Stevens, J. (1992). Applied Multivariate Statistics for The Social Sciences (2nd ed.). Hillsdale, New Jork: Lawrence Erlbaum Associates.

Von-Pork, A. (2007). Strategic Management in Islamic Finance.

Yamane, T. (1973). Statistics: An introductory analysis ( $3^{\text {rd }}$ ed.). New York: Harper \& Row.

Youri, D., Yeray, S.G., Lucas, G. (2016). Horticultural and Floriculture in Rwanda. Identification of focus areas for sector Development. LEI Wageningen UR, Netherlands Entreprise Agency (RVO). 